\title{
Effect of Acylated Proteins on Textural Properties of Nonfat Low Calorie Set Yogurt and Lowfat Ice Cream
}

\author{
Khalid FAROOQ and Zahur U. HAQUE* \\ Department of Food Science and Technology, Mississippi Agricultural and Forestry Experiment Station, Mississippi State University, \\ Mississippi State 39762, U.S.A
}

Received December 16, 1996; Accepted June 30, 1997

\begin{abstract}
Acylated $\mathcal{x}$-casein $(\mathrm{kCN})$ and $\beta$-casein $(\beta \mathrm{CN})$ were used $(0.1 \% \mathrm{w} / \mathrm{v})$ to improve textural and flavor properties of nonfat/low calorie yogurt and lowfat ice cream. Acylation was achieved by base-catalyzed ester exchange of $N$-hydroxysuccinimide esters of naturally occurring caprylic (C:8), lauric (C:12), and palmitic (C:16) acids. The degree of modification of the proteins was controlled by adjusting the ratio of fatty acid to protein (1:1 and 2:1). The hydrocarbon chain length was referred to as the "length." Products with the acylated proteins displayed significantly improved texture. Shorter length (C:8) had the best effect. In terms of flavor, longer length provided better improvement of flavor ratings. Stability as assessed by degree of syneresis and gel strength was markedly improved by all acylated proteins and this was particularly true when acylated $\beta C N$ was used. The apparent viscosity of the product was better improved by acylated $\mathrm{kCN}$. Data indicated that acylated proteins markedly improved product quality.
\end{abstract}

Keywords: acylated proteins, textural properties, $\beta$-casein, $\mathcal{x}$-casein, caprylic, lauric, palmitic

The fat content of food systems markedly effects flavor and texture (Morrison, 1990). Unfortunately, a higher intake of fat has been linked with increased risk of coronary heart disease and certain cancers (Anon, 1984), and this has caused an increase in the consumers' concern. In spite of this health hazard, most consumers find it difficult to give up foods high in fats because of better palatability (Morrison, 1990).

Fat content of individual dairy products varies from $1 \%$ for nonfat dry milk to 10 to $15 \%$ for ice cream and $30 \%$ or more for certain cheeses (Morrison, 1990). Dairy products which are potential candidates for fat substitutes vary in fat content from $81 \%$ for butter down to $3 \%$ for yogurt. The potential use of fat substitutes in these items totals 1.27 billion kg (Morrison, 1990).

Yogurt is an increasingly popular cultured dairy product. Its consumption has increased partly because of increased consumer awareness regarding possible health benefits (VanEden, 1988).

Food scientists have devoted considerable time and resources to the development of products which taste like traditional high fat food but contain less fat. In existing reduced fat foods in the market place, mixtures of water and starch (or protein) often replace some of the fat. However, these foods tend not to have the taste and creaminess of their traditional counterparts.

This study evaluated the effect of acylated $\varkappa$-casein $(\mathrm{kCN})$ and $\beta$-casein $(\beta \mathrm{CN})$ on textural properties of nonfat/nosugar-set yogurt and lowfat (3.0\% fat) ice cream. Chemically acylated proteins produced as described before (Haque \& Kito, 1983) were used for these model studies.

* To whom correspondence should be addressed.

\section{Materials and Methods}

Preparation of $\beta C N$ and $k C N$ The $\beta C N$ and $\mathrm{kCN}$ fractions were prepared according to the method of Hipp et al., and Zittle and Custer, respectively (Hipp et al., 1952; Zittle \& Custer, 1963). These proteins were exhaustively dialyzed (10,000-fold) against glass-distilled water, flashfrozen in liquid nitrogen, freeze-dried, and stored at $-20^{\circ} \mathrm{C}$ until needed.

Acylation of proteins Proteins were acylated using naturally occurring fatty acids. Caprylic (C:8), lauric (C:12), and palmitic $(\mathrm{C}: 16)$ acids were used at mole ratios of 1 and 2 with the proteins. Dicyclohexanylcarbo-diamide was used to produce $N$-hydroxysuccinimide esters of the fatty acids which were then attached to the protein surface by base-catalyzed ester exchange as described earlier (Haque \& Kito, 1983). Proteins thus acylated were termed "protein $X-Y$," where $X$ indicated the fatty acid to protein mole ratio ("load") and $Y$ indicated the chain length ("length"). Thus, kCN 1-8 was $x$-casein which had been acylated with a $1: 1$ mole ratio of caprylic acid and so on

Preparation of Ice Cream Ice cream mixes prepared in one liter batches with fresh cream, nonfat milk powder, sucrose (Sysco Coop., Houston, Texas), corn syrup solids 24 DE (Hubinger., Keokuk, IA), and stabilizer (mix containing guar, xanthane \& locust bean gum in equal amounts) were obtained from the Mississippi State University Dairy Plant. Acylated proteins (casein-based) (synthesized and provided by Dr. Z.U. Haque) were used in concentrations of $0.1 \%$ (w/ v) (Table 1). Casein (non-acylated) was used to replace the same amount of acylated protein to maintain the same level of total solids in control samples.

Previously weighed, dry ingredients were mixed and blended with standardized milk at $60^{\circ} \mathrm{C}$. Blended mixes were 
Table 1. Formulation of ice cream mix.

\begin{tabular}{lc}
\hline Ingredient & Percentage of wt/vol \\
\hline Milk fat & 3.0 \\
Solids (non fat) & 13.0 \\
Sucrose & 12.0 \\
Corn syrup solids $^{a)}$ & 6.0 \\
Stabilizer & 0.15 \\
Acylated protein $^{b)}$ & 0.1 \\
\hline Total Solids & 34.25 \\
\hline
\end{tabular}

a) Dry sweet 24 corn syrup solids (Hubinger, Keokuk, IA).

b) Acylated proteins obtained from Protein Chemistry Laboratory, Mississippi State University

homogenized in a single stage valve homogenizer at a pressure of $140 \mathrm{~kg} / \mathrm{cm}^{2}$ (Haque \& Kinsella, 1989). All homogenized mixes were batch-pasteurized at $68^{\circ} \mathrm{C}$ for $30 \mathrm{~min}$ and chilled to $7^{\circ} \mathrm{C}$ before transfer to a cooler at $4^{\circ} \mathrm{C}$ for overnight aging. Before freezing, mixes were flavored with four-fold vanilla extract from Virginia Dare, USA (Four-fold is the concentration obtained from vanilla extract by distilling off a large part of the solvent, in vacuum. Each multiple is derived from an original $13.35 \mathrm{oz}$. of beans in the starting extract before concentration). All batches were frozen in a $4 l$ batch freezer (Model 71, Richmond Ceder Work Manufacturing Corp., Danville, VA). Ice cream was portioned into $250 \mathrm{~g}$ plastic containers and stored at $-26^{\circ} \mathrm{C}$.

Preparation of yogurt Yogurt mixes were prepared as one liter batches from fluid skim milk with $9 \%$ solids (non fat) obtained from the Mississippi State University Dairy Plant as described earlier (Farooq \& Haque, 1992). To increase solids, $3 \%$ nonfat dry milk and $0.5 \%$ modified food starch (National Starch., NJ) were added. The mixture was sweetened with 0.03\% aspartame (NutraSweet-NutraSweet Co., Deerfield, IL). Acylated proteins (synthesized and obtained from Dr. Haque) were used at a concentration of $0.1 \%(w / v)$. The overall total solids content of each yogurt was $12.68 \%$ (Table 2). Previously weighed ingredients were mixed into fluid skim milk heated to $60^{\circ} \mathrm{C}$ followed by homogenization in a singlestage valve homogenizer at a pressure of $105 \mathrm{~kg} / \mathrm{cm}^{2}$ (Haque \& Kinsella, 1989). The homogenized mixes were batchpasteurized at $85^{\circ} \mathrm{C}$ for $30 \mathrm{~min}$ and then rapidly cooled to $38^{\circ} \mathrm{C}$ in an ice bath. The base mixes were inoculated with a thawed culture concentrate of Streptococcus thermophilous and Lactobacillus bulgaricus (Chr. Hansen's Laboratory, Milwaukee, WI). After mixing, the inoculated yogurt mixes were filled into $250 \mathrm{~g}$ plastic cups and incubated at $38^{\circ} \mathrm{C}$. Incubation was terminated at a $\mathrm{pH}$ of 4.5 which required approximately $4 \mathrm{~h}$. The cups were chilled in an ice bath and then refrigerated at $5^{\circ} \mathrm{C}$ for $24 \mathrm{~h}$ before the analyses began. Three readings were recorded for each parameter and mean values were used.

Analytical procedures Samples of ice cream mixes were collected after aging and analyzed for apparent viscosity and $\mathrm{pH}$. Ice cream samples were analyzed after $24 \mathrm{~h}$ of frozen storage for meltdown, syneresis, and sensory evaluation for flavor and body/texture. Yogurt samples were analyzed for $\mathrm{pH}$, apparent viscosity, penetration, syneresis, and sensory evaluation (texture and flavor).
Table 2. Formulation of yogurt mix.

\begin{tabular}{lc}
\hline Ingredient & Percentage of wt/vol \\
\hline Nonfat dry milk & 3.0 \\
Aspartame & 0.03 \\
Starch & 0.5 \\
Acylated protein & 0.1 \\
Yogurt culture & 0.1 \\
Fluid skim milk & 96.27 \\
\hline Total & 100.00
\end{tabular}

\section{Chemical Analysis}

Fat and total solids The Mojonnier method was used to determine the percentage of fat and total solids in the ice cream mixes (Richardson, 1985).

Viscosity Viscosities were measured at $8^{\circ} \mathrm{C}$ using a Brookfield viscometer with a helipath stand. For the ice cream mix, a Brookfield Model HBT (Brookfield Engineering Labs, Inc., Stoughton, MA) was used after aging at $50 \mathrm{rpm}$ with spindle \#H-2. For yogurt, Brookfield Model LVTD was used to record apparent viscosity on cup-set yogurts. Three readings were recorded $5 \mathrm{~s}$ apart, averaged, and converted to centipoise units.

Penetration Gel strength of yogurts was measured with a falling cone type penetrometer (TS 73610 AN-2; Precision Scientific., Chicago, IL). The results were reported as millimeters of penetration.

$p H \quad$ The $\mathrm{pH}$ values were measured using a standardized Cole Palmer Research $\mathrm{pH}$ Meter. The $\mathrm{pH}$ meter was standardized using commercial buffers to $\mathrm{pH} 4$ and 7 (Aldrich Chemical Company, Milwaukee, WI).

Meltdown A $71 \mathrm{~g}$ scoop of ice cream was placed on a wire gauge $\left(10\right.$ wires $\left./ \mathrm{cm}^{2}\right)$ at $22^{\circ} \mathrm{C}$. Liquid drained through the gauge and was collected in a graduated cylinder. Time for collection of the first $10 \mathrm{ml}$ of liquid was recorded. Volume of liquid collected in each subsequent $15 \mathrm{~min}$ period was measured, and a graph was obtained by plotting time against volume collected. Milliliters of meltdown per hour were recorded.

Organoleptic Sensory evaluations were done on coded samples of ice cream and yogurt by a three-member experienced panel with three digits. The Official ADSA Intercollegiate Dairy Products Evaluation Contest Score Card for flavor with a 10 -point scale $(10=$ no criticism, $)$ and for texture with a 5 -point scale $(5=$ no criticism) was used.

Syneresis Serum separation in ice cream samples was measured by centrifugation using a Sorval RC S 280 at 15000 $\mathrm{rpm}$ for $20 \mathrm{~min}$ at $20-25^{\circ} \mathrm{C}$. Serum separation in yogurt samples was measured by inverting $200 \mathrm{~g}$ samples on a fine mesh screen placed on top of a funnel. After $2 \mathrm{~h}$ of drainage at $10^{\circ} \mathrm{C}$, the quantity of whey collected in a $100 \mathrm{ml}$ graduated cylinder was used as an index of syneresis (Faroog \& Haque, 1992).

Statistical analysis All the tests were done in triplicate and the results obtained were analyzed statistically using SAS (SAS, 1988) with following model.

$\mathrm{YiK}=\mathrm{U}+\mathrm{Ti}+\mathrm{eiK}$

$\mathrm{U}=$ grand mean of experiment, 
Table 3. Mean scores for $\mathrm{pH}$, viscosity, and meltdown of lowfat ice cream mixes as affected by treatments.

\begin{tabular}{|c|c|c|c|c|}
\hline \multicolumn{2}{|c|}{ Treatment } & \multirow[b]{2}{*}{$\mathrm{pH}$} & \multirow[b]{2}{*}{$\begin{array}{l}\text { Viscosity }{ }^{b)} \\
\quad(\mathrm{cps})\end{array}$} & \multirow[b]{2}{*}{$\begin{array}{l}\text { Meltdown } \\
\text { (min) }\end{array}$} \\
\hline Code & $\begin{array}{c}\text { Acyl. prot. } \\
\text { type }^{a)}\end{array}$ & & & \\
\hline Control & Nil & $6.3^{\mathrm{a}}$ & $640^{\mathrm{a}}$ & $60^{\mathrm{a}}$ \\
\hline 1 & $\beta C N$ 1-8 & $6.3^{\mathrm{a}}$ & $672^{b}$ & $66^{b}$ \\
\hline 2 & $\beta C N \quad 1-12$ & $6.3^{\mathrm{a}}$ & $565^{c}$ & $69^{c}$ \\
\hline 3 & $\beta C N \quad 1-16$ & $6.3^{\mathrm{a}}$ & $433^{\mathrm{d}}$ & $65^{\mathrm{d}}$ \\
\hline 4 & $\mathrm{kCN} 2-8$ & $6.3^{\mathrm{a}}$ & $704^{e}$ & $65^{\mathrm{d}}$ \\
\hline 5 & $\mathrm{kCN} 2-12$ & $6.3^{\mathrm{a}}$ & $586^{\mathrm{f}}$ & $68^{e}$ \\
\hline 6 & $\mathrm{kCN} 2-16$ & $6.3^{\mathrm{a}}$ & $469^{g}$ & $67^{f}$ \\
\hline
\end{tabular}

$a, b, c, d, e, f, g$ Means with the same letter are not significantly different at $p<0.05$. a) Acylated proteins: As described in the text

b) Viscosity of mix after aging $\left(24 \mathrm{~h}, 5^{\circ} \mathrm{C}\right)$.

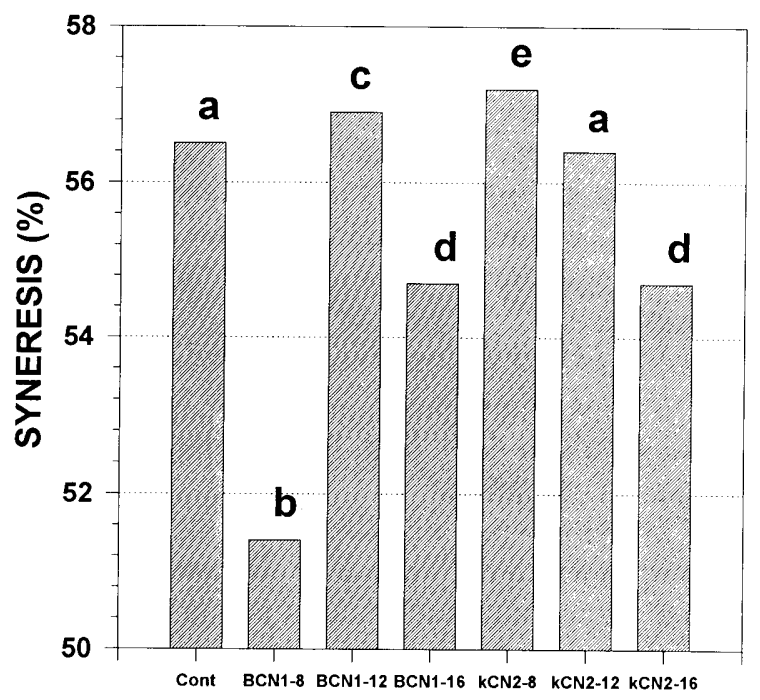

TREATMENT

Fig. 1. Effects of added acylated proteins on the syneresis of lowfat ice cream The $x$-axis represents treatment and the $y$-axis represents syneresis (\%), i.e., the amount of serum separated following centrifuging the sample at $1500 \mathrm{rpm}$.

$T I=$ effect of treatment $i$,

$e i K=$ random error associated with observation $i K$

Calories The caloric content of yogurt and ice cream was calculated on the basis of $8.79 \mathrm{cal} / \mathrm{g}$ for fat, $4 \mathrm{cal} / \mathrm{g}$ for carbohydrates, and $4 \mathrm{cal} / \mathrm{g}$ for protein content (Arbuckle, 1986).

\section{Results and Discussion}

\section{Ice Cream}

Viscosity, $p H$, and stability Ice cream mixes were measured for $\mathrm{pH}$ and viscosity after a $24 \mathrm{~h}$ aging period (Table 3 ). Ice cream containing acylated proteins and the control had identical $\mathrm{pH}$ values which showed that these amounts of acylated proteins do not interfere with the $\mathrm{pH}$ of the system. There was a significant difference in viscosity in all ice cream samples with different treatments even at a level of $0.1 \%(\mathrm{w} /$ v). Overall, ice cream mix with acylated proteins $(\beta \mathrm{CN} 1-8$ and $k \mathrm{CN} 2-8$ ) had significantly higher viscosity compared to the control. A decreasing trend in viscosity was observed for
Table 4. Scores for meltdown volume of lowfat ice cream as affected by treatment.

\begin{tabular}{|c|c|c|c|c|c|}
\hline \multicolumn{2}{|c|}{ Treatment } & \multirow{2}{*}{\multicolumn{4}{|c|}{$\frac{\left.\text { Amount of liquid collected }^{b}\right)(\mathrm{ml})}{\text { Time interval }(\mathrm{min})}$}} \\
\hline \multirow{2}{*}{ Code } & \multirow{2}{*}{$\begin{array}{l}\text { Acyl. } \\
\text { prot. type }\end{array}$} & & & & \\
\hline & & 30 & 45 & 60 & 65 \\
\hline Control & Nil & 15 & 40.0 & 56 & 60 \\
\hline 1 & $\beta C N ~ 1-8$ & 14 & 38.5 & 55 & 66 \\
\hline 2 & $\beta C N \quad 1-12$ & 14 & 38.5 & 55 & 69 \\
\hline 3 & $\beta C N 1-16$ & 14 & 39.0 & 57 & 65 \\
\hline 4 & kCN 2-8 & 13 & 37.5 & 54 & 65 \\
\hline 5 & $\mathrm{kCN} 2-12$ & 14 & 38.0 & 55 & 68 \\
\hline 6 & $\mathrm{kCN} 2-16$ & 14 & 39.0 & 55.5 & 67 \\
\hline
\end{tabular}

a) Acylated proteins. (As in Table 1)

b) Time needed to collect this volume in min at $20^{\circ} \mathrm{C}$.

Table 5. Mean body and texture sensory scores of lowfat ice cream as affected by treatments.

\begin{tabular}{ccc}
\hline \multicolumn{2}{c}{ Treatment } & $\begin{array}{c}\text { Body and texture } \\
\text { score }^{b)}\end{array}$ \\
\hline Code & Acyl. prot. type ${ }^{a)}$ & $3.0^{\mathrm{a}}$ \\
1 & Nil & $4.0^{\mathrm{b}}$ \\
2 & $\beta C N ~ 1-8$ & $4.0^{\mathrm{b}}$ \\
3 & $\beta C N ~ 1-12$ & $4.0^{\mathrm{b}}$ \\
4 & $\beta C N ~ 1-16$ & $4.0^{\mathrm{b}}$ \\
5 & $\mathrm{kCN} \mathrm{2-8}$ & $4.0^{\mathrm{b}}$ \\
6 & $\mathrm{kCN} \mathrm{2-12}$ & $4.0^{\mathrm{b}}$ \\
\hline
\end{tabular}

a,b,c,d Means with the same letter are not significantly different at $p<0.05$.

a) Acylated proteins. (As in Table 1)

b) Judged by an experienced panel using a scale of 1 to 5 with 5 being excellent.

$\beta \mathrm{CN}$ when $\beta \mathrm{CN} 1-12$ and $\beta \mathrm{CN} 1-16$ were used and for $\mathrm{kCN}$ when $\mathrm{kCN} 2-12$ and $\mathrm{kCN} 2-16$ were used. This showed that different acylated proteins have the ability to improve the viscosity of ice cream mixes even at low dosage, thus providing desirable mouthfeel and textural qualities that are important when fats and carbohydrates are reduced in food products.

Acylated proteins have the ability to improve stability of foams and emulsions in lowfat dairy products. Use of acylated proteins, $\beta \mathrm{CN} 1-8, \beta \mathrm{CN} 1-16$, and $k \mathrm{CN} 2-16$, resulted in a significant decrease in serum separation in ice cream samples. Ice cream with acylated protein $(\beta \mathrm{CN} 1-8)$ had the least serum separation at $p<0.05$ (Fig. 1). These results verify that acylated proteins are highly amphipathic and have a tendency to bind tenaciously at the interface of molecules thus producing stable emulsions. Acylated proteins may be used effectively and economically at low concentrations to obtain the desired product viscosity.

Melting quality of ice cream The effect of added acylated proteins treatment on meltdown properties of ice cream is shown in Table 3. Products containing acylated proteins produced the smoothest meltdown and were significantly better than controls $(p<0.05)$. The overall trend of meltdown recorded after each interval is shown in Table 4. These data show that meltdown in ice creams containing acylated proteins was slower compared to the controls. Though the results were significant $(p<0.05)$, difficulty in 


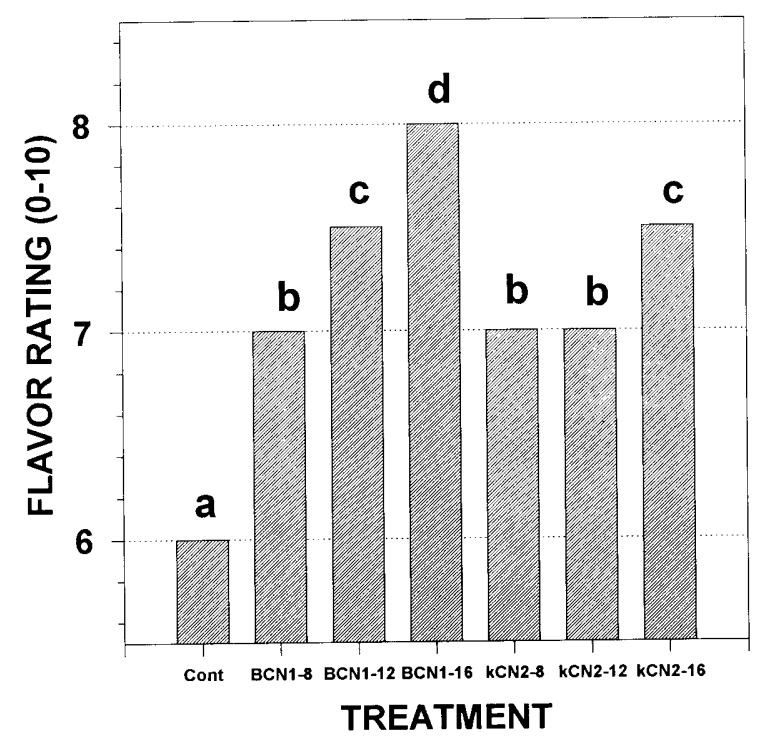

Fig. 2. Effect of added acylated proteins on the flavor of lowfat ice cream. The $x$-axis represents treatment and the $y$-axis represents mean flavor rating on a scale of $0-10$ with 10 being excellent.

Table 6. Effect of treatment on flavor, body, and texture of nonfat low calorie set yogurt.

\begin{tabular}{lcc}
\hline Treatment & Flavor score $^{a)}$ & Body and texture $^{b)}$ \\
\hline Control & $7^{\mathrm{a}}$ & $3^{\mathrm{a}}$ \\
$\beta \mathrm{CN} 1-8$ & $5^{\mathrm{c}}$ & $4^{\mathrm{b}}$ \\
$\beta \mathrm{CN} 1-12$ & $5^{\mathrm{c}}$ & $5^{\mathrm{c}}$ \\
$\beta \mathrm{CN} 1-16$ & $6^{\mathrm{b}}$ & $5^{\mathrm{c}}$ \\
$\mathrm{kCN} \mathrm{2-8}$ & $5^{\mathrm{c}}$ & $5^{\mathrm{c}}$ \\
$\mathrm{kCN} \mathrm{2-12}$ & $5^{\mathrm{c}}$ & $5^{\mathrm{c}}$ \\
$\mathrm{kCN} \mathrm{2-16}$ & $5^{\mathrm{c}}$ & $5^{\mathrm{c}}$ \\
\hline
\end{tabular}

$a, b, c$ Means with the same letter are not significantly different at $p<0.05$.

a) Flavor sensory score on a scale of 1 to 10 with 10 being excellent.

b) Texture sensory score on a scale of 1 to 5 with 5 being excellent.

controlling overrun and drawing temperature when using a batch freezer could lead to variability that affected melting resistance. The ability of acylated proteins to produce smoothness, creaminess, and feel of "warmth" was prominent in the ice creams containing acylated protein when evaluated by sensory analyses.

Sensory evaluation Average flavor and texture scores are presented in Table 5. Ice cream made with acylated proteins was rated better in flavor and textural perception. Ice cream made with acylated proteins $\beta C N \quad 1-16$ was rated significantly better as compared to the control at $p<0.05$ (Fig. 2). It was smoother with a more fat-like tongue feel which was contributed by the acylated proteins.

Yogurt Nonfat low calorie yogurts containing acylated proteins had a firmer body and texture than controls. Mean scores of body and texture are shown in Table 6. Yogurt containing acylated proteins scored 5 which is significantly higher than a score of 3 for the control. The improved firmness, body, and texture seemed to be due to the ability of acylated proteins to contribute creaminess and to possibly
Table 7. Effect of treatment on apparent viscosity, $\mathrm{pH}$, penetration, syneresis of nonfat low calorie set yogurt.

\begin{tabular}{lccc}
\hline Treatment & $\begin{array}{c}\text { Vis. app. (cps) } \\
(10 \times 4)\end{array}$ & $\mathrm{pH}$ & $\begin{array}{c}\text { Penetration } \\
(\mathrm{mm})\end{array}$ \\
\hline Control & $44.1^{\mathrm{a}}$ & $4.4^{\mathrm{a}}$ & $28.2^{\mathrm{a}}$ \\
$\beta C N ~ 1-8$ & $35.1^{\mathrm{b}}$ & $4.4^{\mathrm{a}}$ & $26.5^{\mathrm{b}}$ \\
$\beta C N ~ 1-12$ & $37.7^{\mathrm{c}}$ & $4.4^{\mathrm{a}}$ & $26.8^{\mathrm{c}}$ \\
$\beta C N ~ 1-16$ & $35.2^{\mathrm{d}}$ & $4.4^{\mathrm{a}}$ & $25.9^{\mathrm{a}}$ \\
$\mathrm{kCN} \mathrm{2-8}$ & $35.2^{\mathrm{d}}$ & $4.4^{\mathrm{a}}$ & $28.6^{\mathrm{e}}$ \\
$\mathrm{kCN} \mathrm{2-12}$ & $37.1^{\mathrm{e}}$ & $4.4^{\mathrm{a}}$ & $28.5^{\mathrm{a}}$ \\
$\mathrm{kCN} \mathrm{2-16}$ & $38.6^{\mathrm{r}}$ & $4.4^{\mathrm{a}}$ & $27.8^{\mathrm{s}}$ \\
\hline
\end{tabular}

a,b,c,d,e, Means with the same letter are not significantly different at $p<0.05$.

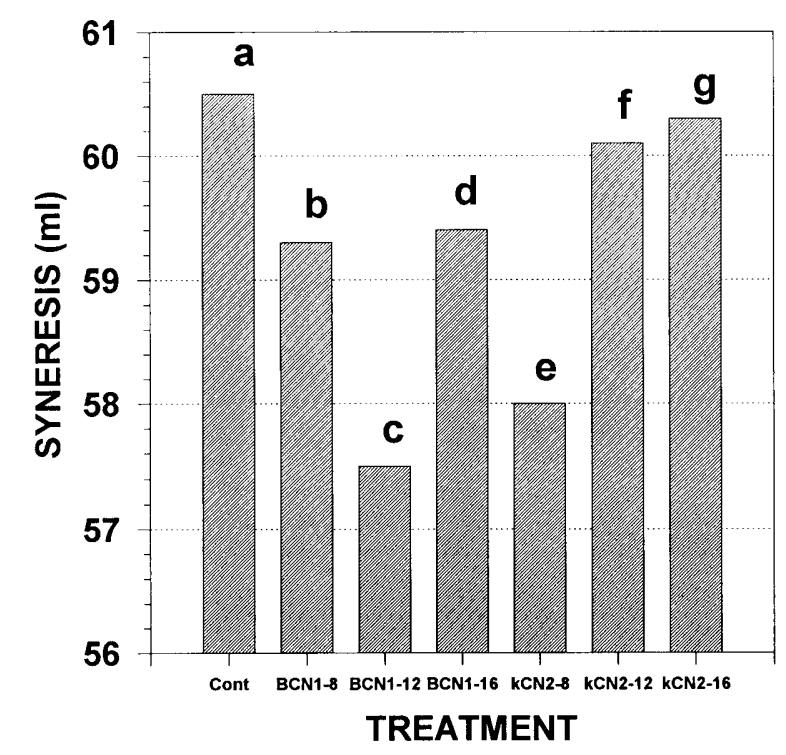

Fig. 3. Effect of added acylated proteins on the syneresis $(\mathrm{ml})$ of nonfat low calorie set yogurts. The $x$-axis represents treatments and the $y$-axis represents the amount of serum separation as observed by the drainage method.

Table 8. Calculated caloric content of nonfat low calorie set yogurt and ice cream, and regular ${ }^{a)}$ yogurt and ice cream.

\begin{tabular}{lccl}
\hline Product & Serving size $(\mathrm{g})$ & $\begin{array}{c}\text { Nonfat/Low } \\
\text { calorie }\end{array}$ & Regular \\
\hline Ice cream & 100.0 & 129.0 & 185.0 \\
Yogurt & 226.8 & 102.5 & 203.54 \\
\hline
\end{tabular}

a) Yogurt with 3.25\% fat and 4\% sucrose, and ice cream with $10 \%$ fat and $12 \%$ sucrose.

form complexes with the stabilizer system.

The effects of treatments on apparent viscosity are shown in Table 7. Results showed that the apparent viscosity was significantly lower for yogurts with acylated proteins. This may be one of the contributors to the improved texture and firmness.

Yogurts with acylated proteins produced less syneresis than the control (Fig. 3). The decreased syneresis in yogurts with acylated proteins seems to be due to their contribution to improve water holding capacity. 
Yogurts with $\beta \mathrm{CN}$ produced strong and firm gels as observed by greater resistance to the penetrating cone. It seems that acylated proteins $(\beta \mathrm{CN})$ improved the gel strength thus showing improved water binding and less syneresis as observed in Table 7.

The $\mathrm{pH}$ of yogurt is an important parameter related to its quality and taste. Too high or too low $\mathrm{pH}$ can affect water holding capacity and thus it can affect whey release. Therefore, it is important to note that at the end of incubation all samples had the same $\mathrm{pH}$ of 4.4 .

Nonfat low calorie set yogurts sweetened with aspartame had only $102.5 \mathrm{cal} / 226.8 \mathrm{~g}$ ( $8 \mathrm{oz}$.) per serving compared to $203.5 \mathrm{cal} / 226 \mathrm{~g}$ per serving of regular yogurt containing $3.25 \%$ fat and 4\% sucrose. Lowfat ice cream had $129 \mathrm{cal} / 100 \mathrm{~g}$ compared to $185 \mathrm{cal} / 100 \mathrm{~g}$ in regular ice cream with $10 \%$ fat (Table 8).

\section{Conclusion}

The results of the study showed that acylated proteins significantly improved the overall textural quality of lowfat ice cream and nonfat low calorie yogurts.

\section{References}

Anon. (1984). Lipid research clinic program: The lipid research clinic's coronary preliminary prevention trial results: II. The relationship of incidence of coronary heart desease to cholesterol lowering. J. Am. Med. Assoc., 251, 365-374.

Arbuckle, W.S. (1986). "Ice Cream," 4th Ed. Van Nostrand Reinhold, Co., New York.

Farooq, K. and Haque, Z.U. (1992). Effect of sugar-esters on the textural properties of nonfat low calorie yogurt. J. Dairy Sci., 75, 2676-2680.

Haque, Z.U. and Kinsella, J.E. (1989). Emulsifying properties of food proteins development of a standardized emulsification method. $J$. Food. Sci. 54, 39-44.

Haque, Z.U. and Kito, M. (1983). Lipophilization of $\alpha$ sl-casein I. Covalent attachment of palmitoyl residue. J. Agric. Food. Chem., 31, 1225-1230

Hipp, N.J., Grover, M.L., Custer, J.H. and McMeekin, T.L. (1952). Separation of $\alpha, \beta$ and gamma-casein. J. Dairy Sci, 35, 272-281.

Morrison, R.M. (1990). The market for fat substitutes. Food Res. Policy, 24-30.

Richardson, G.H. (1985). "Standard Method for the Examination of Dairy Products," 15th Ed. American Public Health Association, Washington, DC.

SAS. (1988). "SAS Procedure Guide," 6.03 Ed. SAS Institute Inc., Cary, NC.

Van-Eden, D. (1988). Growth of yogurt consumption by the American consumer.; Cult-Dairy-Prod-J. Washington, D.C.: American Cultured Dairy Products Institute. Nov 1988. v. 23 (4) p. 26, 30, 32.

Zittle, C.A. and Custer, J.H. (1963). Purification and some of the properties of $\alpha$ s-casein and $\mathcal{x}$-casein. J. Dairy Sci, 46, 1183-1188. 